\title{
The Old and the New: Prospects for Non-Integrating Lentiviral Vector Technology
}

\author{
Luis Apolonia \\ Department of Infectious Diseases, School of Immunology and Microbial Sciences, King's College London, \\ London SE1 9RT, UK; luis.apolonia@kcl.ac.uk
}

Received: 31 August 2020; Accepted: 28 September 2020; Published: 29 September 2020

\begin{abstract}
Lentiviral vectors have been developed and used in multiple gene and cell therapy applications. One of their main advantages over other vectors is the ability to integrate the genetic material into the genome of the host. However, this can also be a disadvantage as it may lead to insertional mutagenesis. To address this, non-integrating lentiviral vectors (NILVs) were developed. To generate NILVs, it is possible to introduce mutations in the viral enzyme integrase and/or mutations on the viral DNA recognised by integrase (the attachment sites). NILVs are able to stably express transgenes from episomal DNA in non-dividing cells or transiently if the target cells divide. It has been shown that these vectors are able to transduce multiple cell types and tissues. These characteristics make NILVs ideal vectors to use in vaccination and immunotherapies, among other applications. They also open future prospects for NILVs as tools for the delivery of CRISPR/Cas9 components, a recent revolutionary technology now widely used for gene editing and repair.
\end{abstract}

Keywords: lentiviral vectors; non-integrating lentiviral vectors (NILVs); insertional mutagenesis; transgene expression; immunotherapy; CRISPR/Cas9

\section{Lentiviral Vectors}

Lentiviral vectors have been derived from human immunodeficiency virus-1 (HIV-1) and developed by segregating the necessary genetic information to form an infectious particle in different plasmids, while removing the capability for replication [1]. Earlier vector generations used three plasmids for vector production: the packaging plasmid that codes for all necessary viral proteins for the particle formation and delivery of the transgene into target cells, the envelope plasmid coding for a glycoprotein that allows for the recognition of target cells, and the transfer vector plasmid that codes for the transgene(s) of interest [2]. In the last generation of these vectors, the regulatory protein Rev was removed from the packaging plasmid and coded from a fourth, distinct plasmid [3].

The envelope plasmid codes for a glycoprotein from a different virus than HIV-1. A commonly used one is the heterologous envelope of vesicular stomatitis virus. This envelope protein allows for the recognition of many target cells and also stabilises the vector particle [4], although other viral proteins have been used. This process is called pseudotyping, and it is a topic covered in another review within this Special Issue [5].

The transfer vector is the viral particle genome coding for the transgene of interest. It is the only RNA in the cell that contains the HIV-1 packaging signal, enabling the specific packaging of this RNA into forming particles. This RNA contains the Rev-responsive element (RRE) that is recognised by the HIV-1 protein Rev, allowing for the nuclear export of unspliced RNA [6]. It also contains all necessary elements for reverse transcription and integration upon target cell transduction. In further developments of the transfer vector, the HIV-1 promoter that sits in the U3 region of the long terminal repeat (LTR) was removed, thus creating self-inactivating (SIN) vectors. These then require a heterologous promoter in the $5^{\prime} \mathrm{LTR}$ in place of the $\mathrm{U} 3$ region to allow the transcription of 
full-length transfer vector mRNA for incorporation into vector particles and do not rely on the viral protein Tat for transcription in the producer cells [7]. Additional modifications to the original transfer vector included the incorporation of a central polypurine tract (cPPT) that can increase the nuclear import of the viral DNA [8,9] and the incorporation of the post-translational regulatory element of the woodchuck hepatitis B virus (WPRE), shown to improve transgene expression levels by facilitating the nuclear export of transcripts that contain this element [10].

The packaging plasmid codes for structural and enzymatic proteins necessary for particle formation and further viral life steps until the transfer vector is integrated into the target cell genome. Gag (structural) polyproteins assemble into particles and recruit the vector genome. The enzymatic polyprotein Pol is composed of the viral protease that cleaves the polyproteins allowing for particle maturation, reverse transcriptase (RT), that reverse transcribes the RNA genome into double stranded DNA. This genetic material can then be integrated into the target cell genome by the viral integrase (IN) protein.

Once integrated, the viral genome becomes part of the target cell genome. It is replicated along all genes into the daughter cells during division, and it is transcribed like a normal cellular gene via its own promoter and polyA signal. Although the resulting RNA, unlike most cellular RNAs, does not contain introns, it can exit the nucleus into the cytoplasm, where it will be translated by the host cell machinery.

\section{Insertional Mutagenesis Safety Concerns and the Rise of Non-Integrating LVs (NILVs)}

An advantage of retroviral-based vectors compared with other viral-based vectors is the stable integration of the transgene into the host genome, thereby achieving sustained transgene expression even if the cells divide [1]. Nevertheless, this hallmark can also become problematic. In fact, there were several adverse events detected in clinical trials, later described, due to insertional mutagenesis [11,12]. In these trials, patients suffering from severe combined immunodeficiency (SCID)-X1 were successfully treated. This disease is an X-linked inherited disorder characterised by an early block to $\mathrm{T}$ and natural killer lymphocyte differentiation caused by mutations of the gene encoding the common cytokine receptor $\gamma$-chain subunit, important for the delivery of growth, survival, and differentiation signals to early lymphoid progenitors. The patients were then treated by using $\gamma$-retroviral vectors to deliver a corrected version of the gene to hematopoietic stem cells ex vivo, thus correcting the gene defect, with subsequent injection of the cells into the patients [11,12]. However, this procedure led to the origin of leukaemia in the treated patients. These events were characterised by insertional transactivation of oncogenes (such as LMO2) by the retroviral vector promoter that led to the uncontrolled clonal expansion of T cells in the patients [13-15]. Additional insertional mutagenesis events were observed in other gene therapy clinical trials using integrating retroviral vectors, such as in Wiskott-Aldrich syndrome (WAS), X-linked chronic granulomatous disease (CGD) or $\beta$-Thalassemia trials with loss of polyclonality of corrected cells. In the WAS trial, a $\gamma$-retroviral vector was used to deliver the corrected WAS protein gene to autologous haematopoietic stem cells, which were then transplanted into patients. This successful trial observed a sustained and partial or full resolution of the disease in 9 out of 10 patients. However, 7 patients developed acute leukaemias associated with dominant clones that harboured vector integrations within or close to the LMO2, MDS1 and MN1 genes' locus [16]. CGD is characterised by a defect in the oxidative antimicrobial activity of phagocytes, resulting from mutations in the gp91(phox) gene. It was observed in this gene therapy clinical trial that the insertional activation of MDS1-EVI1, PRDM16 and SETBP1 increased the expansion of the gamma-retroviral vector-corrected cells in the treated individuals, potentiating the clinical benefit to patients [17]. However, later findings linked insertional activation of EVI1 to genomic instability, monosomy 7 and clonal progression toward myelodysplasia [18]. Similarly, a dominant, myeloid-based cell clone with the HMGA2 gene activated by insertion of the integrated lentiviral vector may have increased the therapeutic efficacy of the treatment in a $\beta$-Thalassemia gene therapy trial [19]. 
It was then evident that further vector development was necessary to reduce these adverse outcomes and the self-inactivating (SIN) vector design was shown to improve the biosafety profiles of these vectors $[20,21]$. Nonetheless, integration may not need to occur in certain applications, and a design where these vectors would not be able to integrate their genome into the target cells could increase the safety profile of lentiviral vectors even further.

\section{Non-Integrating Lentiviral Vector Development}

Integration of the provirus into the host cell DNA is an important step of retroviruses. It ensures that the viral DNA is replicated and transmitted to the daughter cells during cell division. Four main components are necessary for integration to occur: the viral DNA, the target DNA, the viral enzyme integrase and host factors. The integrase viral enzyme is a proteolytic product of Pol and is composed of three domains: the N-terminal domain, which contains a zinc-binding motif [22] and binding of a zinc ion promotes multimerization of this protein [23]; the central domain that contains the catalytic core DD35E motif [24]; the C-terminal domain that has DNA-binding properties [25]. The host-factor LEDGF/p75 is utilised by integrase to facilitate host-cell chromatin binding and targeting lentiviral DNA integration [26,27]. Integration occurs in two catalytic steps: the viral integrase binds to the viral double-stranded DNA in the attachment (att) sites, which are two sets of conserved CA dinucleotides at the end of each of the viral LTRs, and removes the adjacent dinucleotide, in a process called $3^{\prime}$ processing [28]. In the second catalytic step, named strand transfer, integrase mediates a concerted nucleophilic attack by the $3^{\prime}$-hydroxyl residues of the viral DNA on phosphodiester bridges located on either side of the major groove in the target DNA and a transesterification reaction where the viral $3^{\prime}$ ends are ligated to the $5^{\prime}$-O-phosphate residues of the target DNA [29]. The final step is the removal of the unpaired $5^{\prime}$ ends of the viral DNA and the filling of the single-stranded gaps between the $5^{\prime}$ end of the viral DNA and the host DNA, done by the host DNA repair machinery. A schematic representation of these processes is depicted in Figure 1.

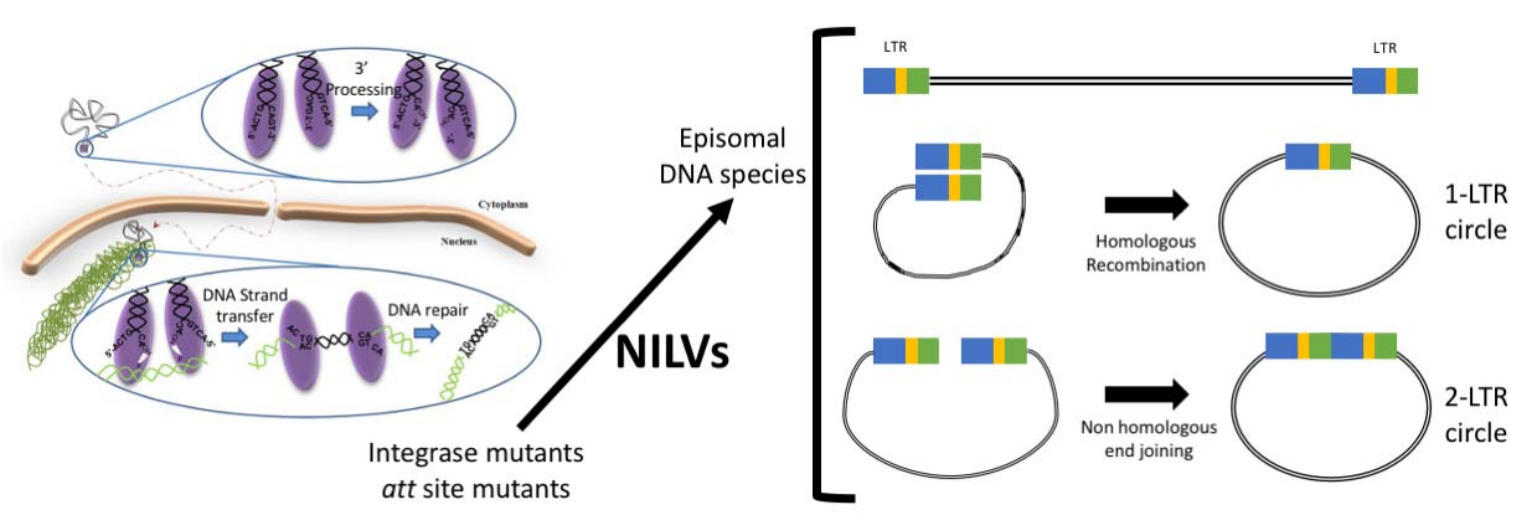

Figure 1. Schematic diagram of integration process, with $3^{\prime}$ processing depicted where the viral enzyme integrase removed a dinucleotide from the ends of the viral DNAs, while binding to the attachment (att) sites and the nucleophilic attack of the recessive ends to the target genome in a catalytic process called DNA strand transfer. Integrase and/or att mutations render these vectors non-integrative, giving origin to episomal vector DNA species that can either be linear or circular, with the latter being the origin of homologous recombination (originating one-LTR (long terminal repeat) circles) or products of non-homologous end-joining (circles with two LTRs).

Interestingly, in addition to the integrated provirus, other extrachromosomal viral DNA species were identified early in retrovirus research $[30,31]$. These viral DNA molecules can either be linear or circular, with the latter being a product of homologous recombination between the viral LTRs (resulting in a DNA circle with only one LTR) or the result of non-homologous end-joining (hence, DNA circles with two LTRs) [32]. Additionally, there are other viral DNA circles produced by intramolecular integration [33]. The viral 2LTR circle molecules can only be formed in the nucleus and have been used 
as surrogates to assess nuclear entry. It was originally thought that these extrachromosomal molecules were by-products of integration and/or viral DNA dead ends. However, it was later proposed that these DNA molecules could support transcription [34-36]. Taking these observations together, Yanez-Munoz and colleagues tested lentiviral vectors that did not integrate their genome into host chromosomes and clearly demonstrated that these vectors maintained full capacity for transgene expression in target cells both in vitro and in vivo [37].

There are two main approaches to generate non-integrating lentiviral vectors: mutation of the viral enzyme responsible for the catalysis of this reaction or inhibiting the recognition of the viral DNA by this enzyme, by mutating or deleting the att sites. These mutations impede the integration of the viral DNA, thus increasing the episomal vector molecules (Figure 1).

With the discovery of the viral enzyme responsible for the stable integration of viral genome into the host chromosomes, and the molecular detail necessary for this reaction, including the catalytic site of this enzyme, the effect of mutations on the integration of vector DNA was investigated. Mutation of any amino acid of the catalytic triad (in HIV-1, these are D64, D116 and E152 residues) results in a catalytic-dead enzyme, therefore increasing the amount of unintegrated vector DNA while reducing the amount of DNA molecules that stably integrate into the host chromosomes up to 1000 fold [38]. Other individual IN mutations have a similar effect, although to a lesser extent (5- to 20-fold lower integration): H12A, N120L, Q148A, Q168L, F185A, W235E, K264R, K266R, and K273R [39-41].

Mutation or deletion of the att site also impairs IN-mediated integration of the viral DNA. These mutations can reduce integration up to 10000-fold [42]. However, the combination of mutations in the viral DNA and in the viral integrase can reduce illegitimate or background integration but does not act synergistically to lower integration much further [40,43].

Kantor and colleagues have recently reported another method to reduce integration of lentiviral vector DNA molecules. They postulated that reducing the formation of linear episomes would further decrease integrase-independent integration events. They show that deletion of the PPT (the viral sequence that acts as primer for plus-strand synthesis) from the vector genome resulted in the increase of 1LTR circle formation prior to the completion of RT, thus reducing the formation of linear DNA molecules and, concomitantly, the formation of 2LTR circles. This PPT-deleted vector reduced integration 10-fold and contributed additionally to a mutation in the viral IN to decrease integration a further $\sim 3$-fold [44]. The same laboratory has also reported the development of a stable NILV packaging cell line that may aid in the production of clinical-grade vectors, comprising the D64E IN mutant together with a conditional self-inactivating vector and a deleted PPT [45], as well as the development of a vector genome with the expression cassette in opposite orientation to the viral LTR, which reduces mobilisation of vectors [46].

\section{Expression Levels of NILVs and Other Vector Designs}

NILVs have been associated with lower expression levels in comparison to their integration-competent counterparts. It has been reported that these vector episomal DNAs are organised in nucleosomes and that modification of histones in these chromatin structures are typically associated with silenced chromatin, such as low levels of acetylation of H3 and H4, low level of dimethylation of H3-K4 and high levels of trimethylated H3-K9; importantly, the report also shows that HDAC inhibitors increased expression from episomal lentiviral vectors [47].

Expression levels may be important in certain applications of these vectors in clinical settings, where high expression of a transgene is required. Several approaches to increase expression could be explored, such as stronger promoter or enhancer elements, codon-optimisation techniques to improve translation of the desired transgenes, or the use of histone deacetylase inhibitors to activate transcription [48]. Other approaches include the removal of cis-acting elements from the U3 region of the LTR [49] or adding other cis-elements to enhance transcription, such as the IS2 element, a synthetic scaffold attachment region combined with the chicken haemoglobin HS4 insulator [47]. Yet another approach has been the use of viral proteins known to alter and optimise the host cell for increased 
transgene delivery and expression, such as Vpr [36] and Vpx [50,51], or the alteration of the cell conditions via drug treatment. Examples of the latter, although not specific for NILVs, include: target cell treatment with rapamycin, which enhances post-binding endocytic events via mammalian target of rapamycin (mTOR) inhibition [52]; treatment with caraphenol A, a cyclic resveratrol trimer that alters the levels of interferon-induced transmembrane (IFITM) proteins IFITM2 and IFITM3 and their association with late endosomes, thus augmenting lentiviral core escape from the endosomal compartment [53]; treatment with the pyrimidoindole derivative UM171 that acts via an unknown mechanism [54]. Although untested in the NILV format, the treatment of hematopoietic stem cells with Cyclosporine $\mathrm{H}$ augmented transduction of integrating lentiviral vectors by downmodulating IFITM3 [55], and, through a not yet identified mechanism, the use of PGE2 [56] or proteasome inhibitors $[57,58]$ also increased transduction of lentiviral vectors. These may be other alternatives to increase the transduction efficiency of NILVs.

Importantly, the mechanism by which vector episomal DNA results in lower expression of transgenes compared with integrated DNA is still unknown and warrants further investigation, potentially allowing the development of vectors that can circumvent this possible limiting step for the application of NILVs.

Other vector designs involved the use of NILVs to deliver genetic material that are then maintained episomally. This was accomplished by introducing the SV40 or EBV origins of replication in the NILV genome and the delivery of these vectors into cells expressing the SV40 large T antigen or the EBV nuclear antigen 1, respectively [59,60]. Alternatively, the use of a scaffold/matrix attachment region [61-64] or a transient induction of cell cycle arrest [65] also allows prolonged expression, even if the cells divide. Ultimately, safer gene addition therapies in dividing cells could be achieved by the use of NILVs to deliver the transgene that can then be the substrate of other integrating systems that display a safer integration profile compared to HIV-1 integrase-for example, the sleeping beauty transposase [66] or the Flp recombinase [67].

\section{Old and Current Applications of NILVs}

As discussed above, NILVs may have a safer profile than their integrating-competent counterparts, and when integration of the transgene is not necessary, for example, if the target cells are post-mitotic, the use of NILVs may be advantageous. Several studies have demonstrated sustained, long-term expression in many cell types and tissues, both in vitro and in vivo [37,40,68-71]. Additionally, NILVs have also demonstrated efficacy in pre-clinical models, such as retinal degeneration [37], Parkinson's disease [72], Haemophilia B [73], or traumatic brain injury [74].

Other applications where non-integrating vectors may be important vectors of choice are those when transient expression is preferred. These include vaccination, cellular differentiation, delivery of cytotoxic cancer therapies, or as donor template delivery for homologous recombination and site-directed/specific integration systems.

Vaccination is an application where only transient expression is required and desirable. NILVs are therefore ideal candidates as vectors for this application and have been shown to elicit an efficient and sustained immune response both from intramuscular and sub-cutaneous injections, with prolonged CD8+ T cell responses and antibody production [75-78]. Several pre-clinical studies have shown the efficacy of NILVs in raising an immune response against HIV-1 [77,79-82], influenza virus [83-85], Zika virus [86], human papillomavirus [87], vaccinia virus [88], West Nile virus [89], human cytomegalovirus [90], Hepatitis B virus [75], and malaria [91]. NILVs have also been designed to specifically target professional antigen presenting cells, by using the Sindbis virus envelope glycoprotein that specifically targets DCs via the receptor DC-SIGN, which is expressed by these cells [92].

NILVs have also been utilised as vectors of choice for cancer immunotherapy $[75,78,88,93-96]$. These vectors have been successfully used to deliver immunogens to dendritic cells, professional antigen presenting cells that can directly prime CD8+ T cell responses. Of importance, one such vector has been now tested in the clinic. The LV305 vector has the mutation D64V in the viral integrase and is 
a dendritic cell-targeted vector that expresses the New York oesophageal squamous cell carcinoma-1 (NY-ESO-1) cancer testis antigen from a PPT-deleted vector genome. It was first reported as successfully treating a patient with metastatic and recurrent synovial sarcoma that was NY-ESO-1 therapy-refractive. This patient had been enrolled in a phase I dose-escalation clinical trial to evaluate the LV305 vectors. She received three doses of $5 \times 10^{\wedge} 8$ vector genomes via intradermal injection showing no severe adverse events. Reportedly, the tumour in this patient shrunk 85\% below baseline 24 months after LV305 injection. Importantly, the report shows sustained NY-ESO-1-specific CD4+ and CD8+ T cell responses that were sustained for up to two years after immunisation with the NILV [93]. In the first results of this clinical trial, it was reported that 39 patients had been enrolled, with tumour types including sarcoma, ovarian cancer, melanoma and lung cancer. The dose escalation ranged from three doses of $10^{\wedge} 8$ vector genomes to four doses of $10^{\wedge} 10$ vector genomes. Importantly, no dose-limiting toxicities were observed, and no patient reported a treatment-related severe adverse event. Secondary objectives of this trial included the assessment of immunogenicity. Despite the low number of enrolled patients, exploratory analysis showed that the disease control rate was 56\%. Anti-NY-ESO-1 CD4+ and CD8 $+\mathrm{T}$ cell responses were observed in $57 \%$ of patients, and these responses were correlated with increased survival rate one-year post treatment [95].

Another study applied NILVs to treat cancer using a different approach, by turning NILVs into oncolytic viruses: NILVs expressing the diphtheria toxin A, an immunotoxin widely used in cancer treatment, under the control of the survivin promoter, a highly active promoter in tumour cells, were shown to inhibit tumour growth in immunodeficient nude mice [97].

One important area of scientific development is gene repair via endogenous homologous recombination. Here, NILVs have been used to deliver genetic material that can then be used as template for homologous recombination and thus gene editing of target cells [98]. However, the introduction of a double-strand break at the site of interest can enhance homologous recombination, and this can be achieved by the use of enzymes that specifically recognise target sequences, such as meganucleases and zinc finger nucleases (ZFNs). Lombardo and colleagues explored ZFNs to specifically integrate transgenes into the CCR5 and AAVS1 locus using NILVs. They demonstrated 7-12\% efficiency of homologous recombination [99], while the iSCeI meganuclease was successfully utilised in gene repair in other reports $[39,100]$. Other groups showed pre-clinical efficiency of ZFNs in relevant disease models, such as adenosine deaminase deficiency [101], X-SCID [102,103], and $\beta$-thalassemia [104] or meganucleases for Duchenne muscular dystrophy [105].

The generation of induced pluripotent stem (iPS) cells is another area where transient expression is sufficient and desired and where NILVs have been tested. One study compared the generation of these cells by NILVs and their counterparts. It was found that, although NILVs were able to generate iPS cells, the efficiency was $~ 50$-fold lower compared to their integrating counterparts, and that regardless of the vector system used, all generated clones had an integrated copy of the SV40 large T antigen gene (most likely arising from illegitimate integration in NILVs) [106]. However, sorting and identification of cells by transient expression of easily assessed transgenes by NILVs was shown to be effective [107,108].

\section{Prospects for NILV Technology}

The development of clustered regularly interspaced short palindromic repeats/CRISPR- associated protein 9 (CRISPR/Cas9) technologies that allow for the targeting of chromosomal DNA, introducing nicks or double-strand breaks at specific sequences and permitting precise editing of target DNA, opened a new avenue for the application of NILVs. Ideally, after the desired DNA editing event has occurred, Cas9 protein and guide RNA are not needed, and the genetic information should be deleted or lost from the cell to prevent off targets and undesirable side effects. Therefore, the use of a non-integrating vector is preferable, making NILVs highly attractive tools for this application: their genetic cargo is enough to accommodate the expression of the CRISPR/Cas9 protein as well as transcription of the guide RNA - necessary components for specific targeting and editing. The low immunogenicity of these vectors combined with the broad or specific cell targeting conferred by the 
choice of envelope pseudotyping is also advantageous. Indeed, it has already been demonstrated that these vectors are efficacious for such applications. In one study, HEK293T cells ectopically expressing green fluorescent protein (GFP) were transduced with NILVs expressing CRISPR/Cas9 and a guide RNA specifically targeting GFP to demonstrate the efficiency of this system. Additionally, this study measured on-target mutations and compared the results to integrating lentiviral vectors. The study found that on-target efficiency of NILVs was very similar to their integrating counterparts $(80 \%$ compared to $84 \%$, respectively). Importantly, off-target effects were also studied: while integrating lentiviral vectors were able to potentially introduce undesired mutations in 3.4 to $24 \%$ of 16 potential off-target genes, NILVs showed close to baseline mutations or only a slight increase of mutations relative to background in those genes [109]. NILVs have also been used to correct mutations in target cells, thus potentially ameliorating a disease. Surun and colleagues have shown that a non-integrating lentiviral vector expressing CRISPR/Cas9 and a guide RNA targeting the cytochrome b-245 heavy chain (whose lack of expression results in chronic granulomatosis disease) can be used to correct this defect in hematopoietic cells [110]. Izmiryan and colleagues corrected the gene responsible for recessive dystrophic epidermolysis bullosa, COL7A1, using an NILV design. Using an ex vivo approach, they were able to show successful correction of the gene in primary keratinocytes and fibroblasts. Of interest, this study also showed no non-specific cleavage of potential off-target hits and no expression of CRISPR/Cas9 one and two months after engrafting the corrected cells in mice [111]. Ortinski et al. targeted $\gamma$-amino-butyric acid A receptor subunit a2 by knocking out the expression of this protein and demonstrated the feasibility of this system in vivo in neurons [109]. Similarly, Hu and colleagues used NILVs to express CRISPR/Cas9 transiently in cells to introduce mutations in syngeneic cells that can then be transplanted in immunocompetent mice without the rejection of those cells. Using this technology, they reported the successful establishment of a von Hippel-Lindau gene-deleted metastatic renal cell carcinoma model in immunocompetent animals [112].

NILVs may also be the vectors of choice for the delivery of the DNA template necessary for homologous recombination. Importantly, it is plausible to speculate that there may be designs to allow for an all-in-one design to provide the DNA template sequence from the same vector that also expresses the Cas9 protein and guide RNA necessary to enhance this cellular process. This vector design would possibly increase the efficiency of these vectors to correct known mutations in the target DNA or to introduce known mutations to generate important disease model cells, in comparison to supplying the homology DNA template in a separate vector.

\section{Conclusions}

This review described the development of NILVs, achieved by mutating the viral integrase or the att sites in the viral DNA where this enzyme binds, and summarised the current and potential applications for these vectors. Originally, NILVs were developed to circumvent the potential insertional mutagenesis hazard posed by their integrating counterparts. It was shown that NILVs were able to sustain prolonged transgene expression in post-mitotic cells. Although lower expression levels are achieved by the episomal vector molecules compared with their integrating counterparts, several methods were applied to boost expression from those molecules. Nonetheless, further research should address this potential issue to elucidate this mechanism and guide other developments of these vectors.

The transient expression nature of NILVs in dividing cells, combined with their low immunogenicity and potential cell targeting through the use of pseudotyping and/or cell-specific promoters makes them ideal vector candidates to be used in applications that require temporary expression, such as vaccination, immunotherapies and the up-and-coming gene repair/editing techniques. With the revolutionary exploitation of CRISPR/Cas9 technology for easy genetic modification, including precise editing, it is conceivable that NILVs may be used as the delivery method of choice. NILVs' intrinsic characteristics and their genetic cargo space that may be able to accommodate all required elements to achieve genetic editing (including the guide RNA, the Cas9 
protein and, potentially, the DNA sequence to be used as template for genetic modification) are advantageous for the delivery of this system to target cells.

Overall, new avenues for applications of NILVs can be envisaged in the near future, so it is probable that we have not seen the last of these vectors yet.

Funding: This research received no external funding.

Conflicts of Interest: The author declares no conflict of interest.

\section{References}

1. Naldini, L.; Blomer, U.; Gallay, P.; Ory, D.; Mulligan, R.; Gage, F.H.; Verma, I.M.; Trono, D. In Vivo Gene Delivery and Stable Transduction of Nondividing Cells by a Lentiviral Vector. Science 1996, 272, 263-267. [CrossRef] [PubMed]

2. Zufferey, R.; Nagy, D.; Mandel, R.J.; Naldini, L.; Trono, D. Multiply Attenuated Lentiviral Vector Achieves Efficient Gene Delivery in Vivo. Nat. Biotechnol. 1997, 15, 871-875. [CrossRef] [PubMed]

3. Dull, T.; Zufferey, R.; Kelly, M.; Mandel, R.J.; Nguyen, M.; Trono, D.; Naldini, L. A Third-Generation Lentivirus Vector with a Conditional Packaging System. J. Virol. 1998, 72, 8463-8471. [CrossRef]

4. Burns, J.C.; Friedmann, T.; Driever, W.; Burrascano, M.; Yee, J.K. Vesicular Stomatitis Virus G Glycoprotein Pseudotyped Retroviral Vectors: Concentration to very High Titer and Efficient Gene Transfer into Mammalian and Nonmammalian Cells. Proc. Natl. Acad. Sci. USA 1993, 90, 8033-8037. [CrossRef]

5. Gutierrez-Guerrero, A.; Cosset, F.L.; Verhoeyen, E. Lentiviral Vector Pseudotypes: Precious Tools to Improve Gene Modification of Hematopoietic Cells for Research and Gene Therapy. Viruses 2020, 12, 1016. [CrossRef] [PubMed]

6. Malim, M.H.; Hauber, J.; Le, S.Y.; Maizel, J.V.; Cullen, B.R. The HIV-1 Rev Trans-Activator Acts through a Structured Target Sequence to Activate Nuclear Export of Unspliced Viral mRNA. Nature 1989, 338, 254-257. [CrossRef]

7. Zufferey, R.; Dull, T.; Mandel, R.J.; Bukovsky, A.; Quiroz, D.; Naldini, L.; Trono, D. Self-Inactivating Lentivirus Vector for Safe and Efficient in Vivo Gene Delivery. J. Virol. 1998, 72, 9873-9880. [CrossRef]

8. Zennou, V.; Petit, C.; Guetard, D.; Nerhbass, U.; Montagnier, L.; Charneau, P. HIV-1 Genome Nuclear Import is Mediated by a Central DNA Flap. Cell 2000, 101, 173-185. [CrossRef]

9. Follenzi, A.; Ailles, L.E.; Bakovic, S.; Geuna, M.; Naldini, L. Gene Transfer by Lentiviral Vectors is Limited by Nuclear Translocation and Rescued by HIV-1 Pol Sequences. Nat. Genet. 2000, 25, 217-222. [CrossRef]

10. Zufferey, R.; Donello, J.E.; Trono, D.; Hope, T.J. Woodchuck Hepatitis Virus Posttranscriptional Regulatory Element Enhances Expression of Transgenes Delivered by Retroviral Vectors. J. Virol. 1999, 73, 2886-2892. [CrossRef]

11. Gaspar, H.B.; Parsley, K.L.; Howe, S.; King, D.; Gilmour, K.C.; Sinclair, J.; Brouns, G.; Schmidt, M.; Von Kalle, C.; Barington, T.; et al. Gene Therapy of X-Linked Severe Combined Immunodeficiency by use of a Pseudotyped Gammaretroviral Vector. Lancet 2004, 364, 2181-2187. [CrossRef]

12. Cavazzana-Calvo, M.; Hacein-Bey, S.; de Saint Basile, G.; Gross, F.; Yvon, E.; Nusbaum, P.; Selz, F.; Hue, C.; Certain, S.; Casanova, J.L.; et al. Gene Therapy of Human Severe Combined Immunodeficiency (SCID)-X1 Disease. Science 2000, 288, 669-672. [CrossRef] [PubMed]

13. Hacein-Bey-Abina, S.; Garrigue, A.; Wang, G.P.; Soulier, J.; Lim, A.; Morillon, E.; Clappier, E.; Caccavelli, L.; Delabesse, E.; Beldjord, K.; et al. Insertional Oncogenesis in 4 Patients After Retrovirus-Mediated Gene Therapy of SCID-X. J. Clin. Investig. 2008, 118, 3132-3142. [CrossRef] [PubMed]

14. Howe, S.J.; Mansour, M.R.; Schwarzwaelder, K.; Bartholomae, C.; Hubank, M.; Kempski, H.; Brugman, M.H.; Pike-Overzet, K.; Chatters, S.J.; de Ridder, D.; et al. Insertional Mutagenesis Combined with Acquired Somatic Mutations Causes Leukemogenesis Following Gene Therapy of SCID-X1 Patients. J. Clin. Investig. 2008, 118, 3143-3150. [CrossRef] [PubMed]

15. Hacein-Bey-Abina, S.; Von Kalle, C.; Schmidt, M.; McCormack, M.P.; Wulffraat, N.; Leboulch, P.; Lim, A.; Osborne, C.S.; Pawliuk, R.; Morillon, E.; et al. LMO2-Associated Clonal T Cell Proliferation in Two Patients After Gene Therapy for SCID-X1. Science 2003, 302, 415-419. [CrossRef] 
16. Braun, C.J.; Boztug, K.; Paruzynski, A.; Witzel, M.; Schwarzer, A.; Rothe, M.; Modlich, U.; Beier, R.; Gohring, G.; Steinemann, D.; et al. Gene Therapy for Wiskott-Aldrich Syndrome-Long-Term Efficacy and Genotoxicity. Sci. Transl. Med. 2014, 6, 227ra33. [CrossRef]

17. Ott, M.G.; Schmidt, M.; Schwarzwaelder, K.; Stein, S.; Siler, U.; Koehl, U.; Glimm, H.; Kuhlcke, K.; Schilz, A.; Kunkel, H.; et al. Correction of X-Linked Chronic Granulomatous Disease by Gene Therapy, Augmented by Insertional Activation of MDS1-EVI1, PRDM16 Or SETBP1. Nat. Med. 2006, 12, 401-409. [CrossRef]

18. Stein, S.; Ott, M.G.; Schultze-Strasser, S.; Jauch, A.; Burwinkel, B.; Kinner, A.; Schmidt, M.; Kramer, A.; Schwable, J.; Glimm, H.; et al. Genomic Instability and Myelodysplasia with Monosomy 7 Consequent to EVI1 Activation After Gene Therapy for Chronic Granulomatous Disease. Nat. Med. 2010, 16, 198-204. [CrossRef]

19. Cavazzana-Calvo, M.; Payen, E.; Negre, O.; Wang, G.; Hehir, K.; Fusil, F.; Down, J.; Denaro, M.; Brady, T.; Westerman, K.; et al. Transfusion Independence and HMGA2 Activation After Gene Therapy of Human Beta-Thalassaemia. Nature 2010, 467, 318-322. [CrossRef]

20. Modlich, U.; Bohne, J.; Schmidt, M.; von Kalle, C.; Knoss, S.; Schambach, A.; Baum, C. Cell-Culture Assays Reveal the Importance of Retroviral Vector Design for Insertional Genotoxicity. Blood 2006, 108, 2545-2553. [CrossRef]

21. Bokhoven, M.; Stephen, S.L.; Knight, S.; Gevers, E.F.; Robinson, I.C.; Takeuchi, Y.; Collins, M.K. Insertional Gene Activation by Lentiviral and Gammaretroviral Vectors. J. Virol. 2009, 83, 283-294. [CrossRef] [PubMed]

22. Johnson, M.S.; McClure, M.A.; Feng, D.F.; Gray, J.; Doolittle, R.F. Computer Analysis of Retroviral Pol Genes: Assignment of Enzymatic Functions to Specific Sequences and Homologies with Nonviral Enzymes. Proc. Natl. Acad. Sci. USA 1986, 83, 7648-7652. [CrossRef] [PubMed]

23. Zheng, R.; Jenkins, T.M.; Craigie, R. Zinc Folds the N-Terminal Domain of HIV-1 Integrase, Promotes Multimerization, and Enhances Catalytic Activity. Proc. Natl. Acad. Sci. USA 1996, 93, 13659-13664. [CrossRef] [PubMed]

24. Engelman, A.; Craigie, R. Identification of Conserved Amino Acid Residues Critical for Human Immunodeficiency Virus Type 1 Integrase Function in Vitro. J. Virol. 1992, 66, 6361-6369. [CrossRef]

25. Mumm, S.R.; Grandgenett, D.P. Defining Nucleic Acid-Binding Properties of Avian Retrovirus Integrase by Deletion Analysis. J. Virol. 1991, 65, 1160-1167. [CrossRef]

26. Maertens, G.; Cherepanov, P.; Pluymers, W.; Busschots, K.; De Clercq, E.; Debyser, Z.; Engelborghs, Y. LEDGF/p75 is Essential for Nuclear and Chromosomal Targeting of HIV-1 Integrase in Human Cells. J. Biol. Chem. 2003, 278, 33528-33539. [CrossRef]

27. Ciuffi, A.; Llano, M.; Poeschla, E.; Hoffmann, C.; Leipzig, J.; Shinn, P.; Ecker, J.R.; Bushman, F. A Role for LEDGF/p75 in Targeting HIV DNA Integration. Nat. Med. 2005, 11, 1287-1289. [CrossRef]

28. Katzman, M.; Katz, R.A.; Skalka, A.M.; Leis, J. The Avian Retroviral Integration Protein Cleaves the Terminal Sequences of Linear Viral DNA at the in Vivo Sites of Integration. J. Virol. 1989, 63, 5319-5327. [CrossRef]

29. Bushman, F.D.; Craigie, R. Activities of Human Immunodeficiency Virus (HIV) Integration Protein in Vitro: Specific Cleavage and Integration of HIV DNA. Proc. Natl. Acad. Sci. USA 1991, 88, 1339-1343. [CrossRef]

30. Varmus, H.E.; Guntaka, R.V.; Fan, W.J.; Heasley, S.; Bishop, J.M. Synthesis of Viral DNA in the Cytoplasm of Duck Embryo Fibroblasts and in Enucleated Cells After Infection by Avian Sarcoma Virus. Proc. Natl. Acad. Sci. USA 1974, 71, 3874-3878. [CrossRef]

31. Gianni, A.M.; Smotkin, D.; Weinberg, R.A. Murine Leukemia Virus: Detection of Unintegrated Double-Stranded DNA Forms of the Provirus. Proc. Natl. Acad. Sci. USA 1975, 72, 447-451. [CrossRef] [PubMed]

32. Ju, G.; Skalka, A.M. Nucleotide Sequence Analysis of the Long Terminal Repeat (LTR) of Avian Retroviruses: Structural Similarities with Transposable Elements. Cell 1980, 22, 379-386. [CrossRef]

33. Shoemaker, C.; Goff, S.; Gilboa, E.; Paskind, M.; Mitra, S.W.; Baltimore, D. Structure of a Cloned Circular Moloney Murine Leukemia Virus DNA Molecule Containing an Inverted Segment: Implications for Retrovirus Integration. Proc. Natl. Acad. Sci. USA 1980, 77, 3932-3936. [CrossRef]

34. Wu, Y.; Marsh, J.W. Early Transcription from Nonintegrated DNA in Human Immunodeficiency Virus Infection. J. Virol. 2003, 77, 10376-10382. [CrossRef] [PubMed]

35. Engelman, A.; Englund, G.; Orenstein, J.M.; Martin, M.A.; Craigie, R. Multiple Effects of Mutations in Human Immunodeficiency Virus Type 1 Integrase on Viral Replication. J. Virol. 1995, 69, 2729-2736. [CrossRef] [PubMed] 
36. Poon, B.; Chen, I.S. Human Immunodeficiency Virus Type 1 (HIV-1) Vpr Enhances Expression from Unintegrated HIV-1 DNA. J. Virol. 2003, 77, 3962-3972. [CrossRef] [PubMed]

37. Yanez-Munoz, R.J.; Balaggan, K.S.; MacNeil, A.; Howe, S.J.; Schmidt, M.; Smith, A.J.; Buch, P.; MacLaren, R.E.; Anderson, P.N.; Barker, S.E.; et al. Effective Gene Therapy with Nonintegrating Lentiviral Vectors. Nat. Med. 2006, 12, 348-353. [CrossRef]

38. Leavitt, A.D.; Robles, G.; Alesandro, N.; Varmus, H.E. Human Immunodeficiency Virus Type 1 Integrase Mutants Retain in Vitro Integrase Activity Yet Fail to Integrate Viral DNA Efficiently during Infection. J. Virol. 1996, 70, 721-728. [CrossRef]

39. Cornu, T.I.; Cathomen, T. Targeted Genome Modifications using Integrase-Deficient Lentiviral Vectors. Mol. Ther. 2007, 15, 2107-2113. [CrossRef]

40. Apolonia, L.; Waddington, S.N.; Fernandes, C.; Ward, N.J.; Bouma, G.; Blundell, M.P.; Thrasher, A.J.; Collins, M.K.; Philpott, N.J. Stable Gene Transfer to Muscle using Non-Integrating Lentiviral Vectors. Mol. Ther. 2007, 15, 1947-1954. [CrossRef]

41. Emiliani, S.; Mousnier, A.; Busschots, K.; Maroun, M.; Van Maele, B.; Tempe, D.; Vandekerckhove, L.; Moisant, F.; Ben-Slama, L.; Witvrouw, M.; et al. Integrase Mutants Defective for Interaction with LEDGF/p75 are Impaired in Chromosome Tethering and HIV-1 Replication. J. Biol. Chem. 2005, 280, 25517-25523. [CrossRef] [PubMed]

42. Nightingale, S.J.; Hollis, R.P.; Pepper, K.A.; Petersen, D.; Yu, X.J.; Yang, C.; Bahner, I.; Kohn, D.B. Transient Gene Expression by Nonintegrating Lentiviral Vectors. Mol. Ther. 2006, 13, 1121-1132. [CrossRef] [PubMed]

43. Shaw, A.M.; Joseph, G.L.; Jasti, A.C.; Sastry-Dent, L.; Witting, S.; Cornetta, K. Differences in Vector-Genome Processing and Illegitimate Integration of Non-Integrating Lentiviral Vectors. Gene Ther. 2017, 24, 12-20. [CrossRef] [PubMed]

44. Kantor, B.; Bayer, M.; Ma, H.; Samulski, J.; Li, C.; McCown, T.; Kafri, T. Notable Reduction in Illegitimate Integration Mediated by a PPT-Deleted, Nonintegrating Lentiviral Vector. Mol. Ther. 2011, 19, 547-556. [CrossRef]

45. Hu, P.; Li, Y.; Sands, M.S.; McCown, T.; Kafri, T. Generation of a Stable Packaging Cell Line Producing High-Titer PPT-Deleted Integration-Deficient Lentiviral Vectors. Mol. Ther. Methods Clin. Dev. 2015, 2, 15025. [CrossRef]

46. Hu, P.; Bi, Y.; Ma, H.; Suwanmanee, T.; Zeithaml, B.; Fry, N.J.; Kohn, D.B.; Kafri, T. Superior Lentiviral Vectors Designed for BSL-0 Environment Abolish Vector Mobilization. Gene Ther. 2018, 25, 454-472. [CrossRef] [PubMed]

47. Kantor, B.; Ma, H.; Webster-Cyriaque, J.; Monahan, P.E.; Kafri, T. Epigenetic Activation of Unintegrated HIV-1 Genomes by Gut-Associated Short Chain Fatty Acids and its Implications for HIV Infection. Proc. Natl. Acad. Sci. USA 2009, 106, 18786-18791. [CrossRef]

48. Pelascini, L.P.; Janssen, J.M.; Goncalves, M.A. Histone Deacetylase Inhibition Activates Transgene Expression from Integration-Defective Lentiviral Vectors in Dividing and Non-Dividing Cells. Hum. Gene Ther. 2013, 24, 78-96. [CrossRef]

49. Bayer, M.; Kantor, B.; Cockrell, A.; Ma, H.; Zeithaml, B.; Li, X.; McCown, T.; Kafri, T. A Large U3 Deletion Causes Increased in Vivo Expression from a Nonintegrating Lentiviral Vector. Mol. Ther. 2008, 16, 1968-1976. [CrossRef]

50. Negri, D.R.; Rossi, A.; Blasi, M.; Michelini, Z.; Leone, P.; Chiantore, M.V.; Baroncelli, S.; Perretta, G.; Cimarelli, A.; Klotman, M.E.; et al. Simian Immunodeficiency Virus-Vpx for Improving Integrase Defective Lentiviral Vector-Based Vaccines. Retrovirology 2012, 9, 69. [CrossRef]

51. Berger, G.; Goujon, C.; Darlix, J.L.; Cimarelli, A. SIVMAC Vpx Improves the Transduction of Dendritic Cells with Nonintegrative HIV-1-Derived Vectors. Gene Ther. 2009, 16, 159-163. [CrossRef] [PubMed]

52. Wang, C.X.; Sather, B.D.; Wang, X.; Adair, J.; Khan, I.; Singh, S.; Lang, S.; Adams, A.; Curinga, G.; Kiem, H.P.; et al. Rapamycin Relieves Lentiviral Vector Transduction Resistance in Human and Mouse Hematopoietic Stem Cells. Blood 2014, 124, 913-923. [CrossRef] [PubMed]

53. Ozog, S.; Timberlake, N.D.; Hermann, K.; Garijo, O.; Haworth, K.G.; Shi, G.; Glinkerman, C.M.; Schefter, L.E.; D'Souza, S.; Simpson, E.; et al. Resveratrol Trimer Enhances Gene Delivery to Hematopoietic Stem Cells by Reducing Antiviral Restriction at Endosomes. Blood 2019, 134, 1298-1311. [CrossRef] 
54. Ngom, M.; Imren, S.; Maetzig, T.; Adair, J.E.; Knapp, D.J.H.F.; Chagraoui, J.; Fares, I.; Bordeleau, M.E.; Sauvageau, G.; Leboulch, P.; et al. UM171 Enhances Lentiviral Gene Transfer and Recovery of Primitive Human Hematopoietic Cells. Mol. Ther. Methods Clin. Dev. 2018, 10, 156-164. [CrossRef] [PubMed]

55. Petrillo, C.; Thorne, L.G.; Unali, G.; Schiroli, G.; Giordano, A.M.S.; Piras, F.; Cuccovillo, I.; Petit, S.J.; Ahsan, F.; Noursadeghi, M.; et al. Cyclosporine H Overcomes Innate Immune Restrictions to Improve Lentiviral Transduction and Gene Editing in Human Hematopoietic Stem Cells. Cell. Stem Cell. 2018, 23, 820-832.e9. [CrossRef] [PubMed]

56. Heffner, G.C.; Bonner, M.; Christiansen, L.; Pierciey, F.J.; Campbell, D.; Smurnyy, Y.; Zhang, W.; Hamel, A.; Shaw, S.; Lewis, G.; et al. Prostaglandin E2 Increases Lentiviral Vector Transduction Efficiency of Adult Human Hematopoietic Stem and Progenitor Cells. Mol. Ther. 2018, 26, 320-328. [CrossRef]

57. Santoni de Sio, F.R.; Gritti, A.; Cascio, P.; Neri, M.; Sampaolesi, M.; Galli, C.; Luban, J.; Naldini, L. Lentiviral Vector Gene Transfer is Limited by the Proteasome at Postentry Steps in various Types of Stem Cells. Stem Cells 2008, 26, 2142-2152. [CrossRef]

58. Santoni de Sio, F.R.; Cascio, P.; Zingale, A.; Gasparini, M.; Naldini, L. Proteasome Activity Restricts Lentiviral Gene Transfer into Hematopoietic Stem Cells and is Down-Regulated by Cytokines that Enhance Transduction. Blood 2006, 107, 4257-4265. [CrossRef]

59. Vargas, J.; Gusella, G.L.; Najfeld, V.; Klotman, M.E.; Cara, A. Novel Integrase-Defective Lentiviral Episomal Vectors for Gene Transfer. Hum. Gene Ther. 2004, 15, 361-372. [CrossRef]

60. Flynn, R.P.; Zacharias, J.; Zhou, X.; Cannon, M.L.; Philpott, N.J. Non-Integrating Lentiviral Vectors for Specific Killing of Epstein-Barr Virus Nuclear Antigen 1-Positive B Cell Lymphoma Cells. J. Gene Med. 2011, 13, 487-496. [CrossRef]

61. Xu, Z.; Chen, F.; Zhang, L.; Lu, J.; Xu, P.; Liu, G.; Xie, X.; Mu, W.; Wang, Y.; Liu, D. Non-Integrating Lentiviral Vectors Based on the Minimal S/MAR Sequence Retain Transgene Expression in Dividing Cells. Sci. China Life Sci. 2016, 59, 1024-1033. [CrossRef] [PubMed]

62. Chen, F.; Qi, X.; Zhang, R.; Wu, Z.Y.; Yan, C.E.; Li, J.; Liu, Q.Y.; Qi, J. Episomal Lentiviral Vectors Confer Erythropoietin Expression in Dividing Cells. Plasmid 2017, 90, 15-19. [CrossRef]

63. Jin, C.; Fotaki, G.; Ramachandran, M.; Nilsson, B.; Essand, M.; Yu, D. Safe Engineering of CAR T Cells for Adoptive Cell Therapy of Cancer using Long-Term Episomal Gene Transfer. EMBO Mol. Med. 2016, 8, 702-711. [CrossRef] [PubMed]

64. Verghese, S.C.; Goloviznina, N.A.; Skinner, A.M.; Lipps, H.J.; Kurre, P. S/MAR Sequence Confers Long-Term Mitotic Stability on Non-Integrating Lentiviral Vector Episomes without Selection. Nucleic Acids Res. 2014, 42, e53. [CrossRef] [PubMed]

65. Kymalainen, H.; Appelt, J.U.; Giordano, F.A.; Davies, A.F.; Ogilvie, C.M.; Ahmed, S.G.; Laufs, S.; Schmidt, M.; Bode, J.; Yanez-Munoz, R.J.; et al. Long-Term Episomal Transgene Expression from Mitotically Stable Integration-Deficient Lentiviral Vectors. Hum. Gene Ther. 2014, 25, 428-442. [CrossRef] [PubMed]

66. Vink, C.A.; Gaspar, H.B.; Gabriel, R.; Schmidt, M.; McIvor, R.S.; Thrasher, A.J.; Qasim, W. Sleeping Beauty Transposition from Nonintegrating Lentivirus. Mol. Ther. 2009, 17, 1197-1204. [CrossRef] [PubMed]

67. Moldt, B.; Staunstrup, N.H.; Jakobsen, M.; Yanez-Munoz, R.J.; Mikkelsen, J.G. Genomic Insertion of Lentiviral DNA Circles Directed by the Yeast Flp Recombinase. BMC Biotechnol. 2008, 8, 60. [CrossRef]

68. Philippe, S.; Sarkis, C.; Barkats, M.; Mammeri, H.; Ladroue, C.; Petit, C.; Mallet, J.; Serguera, C. Lentiviral Vectors with a Defective Integrase Allow Efficient and Sustained Transgene Expression in Vitro and in Vivo. Proc. Natl. Acad. Sci. USA 2006, 103, 17684-17689. [CrossRef]

69. Peluffo, H.; Foster, E.; Ahmed, S.G.; Lago, N.; Hutson, T.H.; Moon, L.; Yip, P.; Wanisch, K.; Caraballo-Miralles, V.; Olmos, G.; et al. Efficient Gene Expression from Integration-Deficient Lentiviral Vectors in the Spinal Cord. Gene Ther. 2013, 20, 645-657. [CrossRef]

70. Ahmed, S.G.; Waddington, S.N.; Boza-Moran, M.G.; Yanez-Munoz, R.J. High-Efficiency Transduction of Spinal Cord Motor Neurons by Intrauterine Delivery of Integration-Deficient Lentiviral Vectors. J. Control. Release 2018, 273, 99-107. [CrossRef]

71. Rahim, A.A.; Wong, A.M.; Howe, S.J.; Buckley, S.M.; Acosta-Saltos, A.D.; Elston, K.E.; Ward, N.J.; Philpott, N.J.; Cooper, J.D.; Anderson, P.N.; et al. Efficient Gene Delivery to the Adult and Fetal CNS using Pseudotyped Non-Integrating Lentiviral Vectors. Gene Ther. 2009, 16, 509-520. [CrossRef] 
72. Lu-Nguyen, N.B.; Broadstock, M.; Schliesser, M.G.; Bartholomae, C.C.; von Kalle, C.; Schmidt, M.; Yanez-Munoz, R.J. Transgenic Expression of Human Glial Cell Line-Derived Neurotrophic Factor from Integration-Deficient Lentiviral Vectors is Neuroprotective in a Rodent Model of Parkinson's Disease. Hum. Gene Ther. 2014, 25, 631-641. [CrossRef] [PubMed]

73. Suwanmanee, T.; Hu, G.; Gui, T.; Bartholomae, C.C.; Kutschera, I.; von Kalle, C.; Schmidt, M.; Monahan, P.E.; Kafri, T. Integration-Deficient Lentiviral Vectors Expressing Codon-Optimized R338L Human FIX Restore Normal Hemostasis in Hemophilia B Mice. Mol. Ther. 2014, 22, 567-574. [CrossRef] [PubMed]

74. Blanco-Ocampo, D.; Cawen, F.A.; Alamo-Pindado, L.A.; Negro-Demontel, M.L.; Peluffo, H. Safe and Neuroprotective Vectors for Long-Term Traumatic Brain Injury Gene Therapy. Gene Ther. 2020, 27, 96-103. [CrossRef] [PubMed]

75. Karwacz, K.; Mukherjee, S.; Apolonia, L.; Blundell, M.P.; Bouma, G.; Escors, D.; Collins, M.K.; Thrasher, A.J. Nonintegrating Lentivector Vaccines Stimulate Prolonged T-Cell and Antibody Responses and are Effective in Tumor Therapy. J. Virol. 2009, 83, 3094-3103. [CrossRef] [PubMed]

76. Daenthanasanmak, A.; Salguero, G.; Borchers, S.; Figueiredo, C.; Jacobs, R.; Sundarasetty, B.S.; Schneider, A.; Schambach, A.; Eiz-Vesper, B.; Blasczyk, R.; et al. Integrase-Defective Lentiviral Vectors Encoding Cytokines Induce Differentiation of Human Dendritic Cells and Stimulate Multivalent Immune Responses in Vitro and in Vivo. Vaccine 2012, 30, 5118-5131. [CrossRef] [PubMed]

77. Negri, D.R.; Michelini, Z.; Baroncelli, S.; Spada, M.; Vendetti, S.; Buffa, V.; Bona, R.; Leone, P.; Klotman, M.E.; Cara, A. Successful Immunization with a Single Injection of Non-Integrating Lentiviral Vector. Mol. Ther. 2007, 15, 1716-1723. [CrossRef]

78. Hu, B.; Dai, B.; Wang, P. Vaccines Delivered by Integration-Deficient Lentiviral Vectors Targeting Dendritic Cells Induces Strong Antigen-Specific Immunity. Vaccine 2010, 28, 6675-6683. [CrossRef]

79. Negri, D.R.; Michelini, Z.; Baroncelli, S.; Spada, M.; Vendetti, S.; Bona, R.; Leone, P.; Klotman, M.E.; Cara, A. Nonintegrating Lentiviral Vector-Based Vaccine Efficiently Induces Functional and Persistent CD8+ T Cell Responses in Mice. J. Biomed. Biotechnol. 2010, 2010, 534501. [CrossRef]

80. Blasi, M.; Negri, D.; LaBranche, C.; Alam, S.M.; Baker, E.J.; Brunner, E.C.; Gladden, M.A.; Michelini, Z.; Vandergrift, N.A.; Wiehe, K.J.; et al. IDLV-HIV-1 Env Vaccination in Non-Human Primates Induces Affinity Maturation of Antigen-Specific Memory B Cells. Commun. Biol. 2018, 1, 134-136, eCollection 2018. [CrossRef]

81. Gallinaro, A.; Borghi, M.; Pirillo, M.F.; Cecchetti, S.; Bona, R.; Canitano, A.; Michelini, Z.; Di Virgilio, A.; Olvera, A.; Brander, C.; et al. Development and Preclinical Evaluation of an Integrase Defective Lentiviral Vector Vaccine Expressing the HIVACAT T Cell Immunogen in Mice. Mol. Ther. Methods Clin. Dev. 2020, 17, 418-428. [CrossRef] [PubMed]

82. Wee, E.G.; Ondondo, B.; Berglund, P.; Archer, J.; McMichael, A.J.; Baltimore, D.; Ter Meulen, J.H.; Hanke, T. HIV-1 Conserved Mosaics Delivered by Regimens with Integration-Deficient DC-Targeting Lentiviral Vector Induce Robust T Cells. Mol. Ther. 2017, 25, 494-503. [CrossRef] [PubMed]

83. Fontana, J.M.; Christos, P.J.; Michelini, Z.; Negri, D.; Cara, A.; Salvatore, M. Mucosal Immunization with Integrase-Defective Lentiviral Vectors Protects Against Influenza Virus Challenge in Mice. PLoS ONE 2014, 9, e97270. [CrossRef] [PubMed]

84. Negri, D.R.; Bona, R.; Michelini, Z.; Leone, P.; Macchia, I.; Klotman, M.E.; Salvatore, M.; Cara, A. Transduction of Human Antigen-Presenting Cells with Integrase-Defective Lentiviral Vector Enables Functional Expansion of Primed Antigen-Specific CD8(+) T Cells. Hum. Gene Ther. 2010, 21, 1029-1035. [CrossRef] [PubMed]

85. Gallinaro, A.; Borghi, M.; Bona, R.; Grasso, F.; Calzoletti, L.; Palladino, L.; Cecchetti, S.; Vescio, M.F.; Macchia, D.; Morante, V.; et al. Integrase Defective Lentiviral Vector as a Vaccine Platform for Delivering Influenza Antigens. Front. Immunol. 2018, 9, 171. [CrossRef]

86. Ku, M.W.; Anna, F.; Souque, P.; Petres, S.; Prot, M.; Simon-Loriere, E.; Charneau, P.; Bourgine, M. A Single Dose of NILV-Based Vaccine Provides Rapid and Durable Protection Against Zika Virus. Mol. Ther. 2020, 28, 1772-1782. [CrossRef]

87. Grasso, F.; Negri, D.R.; Mochi, S.; Rossi, A.; Cesolini, A.; Giovannelli, A.; Chiantore, M.V.; Leone, P.; Giorgi, C.; Cara, A. Successful Therapeutic Vaccination with Integrase Defective Lentiviral Vector Expressing Nononcogenic Human Papillomavirus E7 Protein. Int. J. Cancer 2013, 132, 335-344. [CrossRef] 
88. Odegard, J.M.; Kelley-Clarke, B.; Tareen, S.U.; Campbell, D.J.; Flynn, P.A.; Nicolai, C.J.; Slough, M.M.; Vin, C.D.; McGowan, P.J.; Nelson, L.T.; et al. Virological and Preclinical Characterization of a Dendritic Cell Targeting, Integration-Deficient Lentiviral Vector for Cancer Immunotherapy. J. Immunother. 2015, 38, 41-53. [CrossRef]

89. Coutant, F.; Frenkiel, M.P.; Despres, P.; Charneau, P. Protective Antiviral Immunity Conferred by a Nonintegrative Lentiviral Vector-Based Vaccine. PLoS ONE 2008, 3, e3973. [CrossRef]

90. Deng, Y.; Guan, J.; Wen, B.; Zhu, N.; Chen, H.; Song, J.; Yang, Y.; Wang, Y.; Tan, W. Induction of Broadly Neutralising HCV Antibodies in Mice by Integration-Deficient Lentiviral Vector-Based Pseudotyped Particles. PLOS ONE 2013, 8, e62684. [CrossRef]

91. Coutant, F.; Sanchez David, R.Y.; Felix, T.; Boulay, A.; Caleechurn, L.; Souque, P.; Thouvenot, C.; Bourgouin, C.; Beignon, A.S.; Charneau, P. A Nonintegrative Lentiviral Vector-Based Vaccine Provides Long-Term Sterile Protection Against Malaria. PLoS ONE 2012, 7, e48644. [CrossRef]

92. Tareen, S.U.; Kelley-Clarke, B.; Nicolai, C.J.; Cassiano, L.A.; Nelson, L.T.; Slough, M.M.; Vin, C.D.; Odegard, J.M.; Sloan, D.D.; Van Hoeven, N.; et al. Design of a Novel Integration-Deficient Lentivector Technology that Incorporates Genetic and Posttranslational Elements to Target Human Dendritic Cells. Mol. Ther. 2014, 22, 575-587. [CrossRef] [PubMed]

93. Pollack, S.M.; Lu, H.; Gnjatic, S.; Somaiah, N.; O’Malley, R.B.; Jones, R.L.; Hsu, F.J.; Ter Meulen, J. First-in-Human Treatment with a Dendritic Cell-Targeting Lentiviral Vector-Expressing NY-ESO-1, LV305, Induces Deep, Durable Response in Refractory Metastatic Synovial Sarcoma Patient. J. Immunother. 2017, 40, 302-306. [CrossRef] [PubMed]

94. Pollack, S.M. The Potential of the CMB305 Vaccine Regimen to Target NY-ESO-1 and Improve Outcomes for Synovial Sarcoma and Myxoid/Round Cell Liposarcoma Patients. Expert Rev. Vaccines 2018, 17, 107-114. [CrossRef]

95. Somaiah, N.; Block, M.S.; Kim, J.W.; Shapiro, G.I.; Do, K.T.; Hwu, P.; Eder, J.P.; Jones, R.L.; Lu, H.; Ter Meulen, J.H.; et al. First-in-Class, First-in-Human Study Evaluating LV305, a Dendritic-Cell Tropic Lentiviral Vector, in Sarcoma and Other Solid Tumors Expressing NY-ESO-1. Clin. Cancer Res. 2019, 25, 5808-5817. [CrossRef]

96. Albershardt, T.C.; Campbell, D.J.; Parsons, A.J.; Slough, M.M.; Ter Meulen, J.; Berglund, P. LV305, a Dendritic Cell-Targeting Integration-Deficient ZVex(TM)-Based Lentiviral Vector Encoding NY-ESO-1, Induces Potent Anti-Tumor Immune Response. Mol. Ther. Oncolytics 2016, 3, 16010. [CrossRef]

97. Lin, B.; Gao, A.; Zhang, R.; Ma, H.; Shen, H.; Hu, Q.; Zhang, H.; Zhao, M.; Lan, X.; Liu, K. Use of a Novel Integrase-Deficient Lentivirus for Targeted Anti-Cancer Therapy with Survivin Promoter-Driven Diphtheria Toxin A. Medicine 2015, 94, e1301. [CrossRef]

98. Okada, Y.; Ueshin, Y.; Hasuwa, H.; Takumi, K.; Okabe, M.; Ikawa, M. Targeted Gene Modification in Mouse ES Cells using Integrase-Defective Lentiviral Vectors. Genesis 2009, 47, 217-223. [CrossRef] [PubMed]

99. Lombardo, A.; Cesana, D.; Genovese, P.; Di Stefano, B.; Provasi, E.; Colombo, D.F.; Neri, M.; Magnani, Z.; Cantore, A.; Lo Riso, P.; et al. Site-Specific Integration and Tailoring of Cassette Design for Sustainable Gene Transfer. Nat. Methods 2011, 8, 861-869. [CrossRef]

100. Izmiryan, A.; Basmaciogullari, S.; Henry, A.; Paques, F.; Danos, O. Efficient Gene Targeting Mediated by a Lentiviral Vector-Associated Meganuclease. Nucleic Acids Res. 2011, 39, 7610-7619. [CrossRef]

101. Joglekar, A.V.; Hollis, R.P.; Kuftinec, G.; Senadheera, S.; Chan, R.; Kohn, D.B. Integrase-Defective Lentiviral Vectors as a Delivery Platform for Targeted Modification of Adenosine Deaminase Locus. Mol. Ther. 2013, 21, 1705-1717. [CrossRef] [PubMed]

102. Abdul-Razak, H.H.; Rocca, C.J.; Howe, S.J.; Alonso-Ferrero, M.E.; Wang, J.; Gabriel, R.; Bartholomae, C.C.; Gan, C.H.V.; Garin, M.I.; Roberts, A.; et al. Molecular Evidence of Genome Editing in a Mouse Model of Immunodeficiency. Sci. Rep. 2018, 8, 8214-8219. [CrossRef] [PubMed]

103. Lombardo, A.; Genovese, P.; Beausejour, C.M.; Colleoni, S.; Lee, Y.L.; Kim, K.A.; Ando, D.; Urnov, F.D.; Galli, C.; Gregory, P.D.; et al. Gene Editing in Human Stem Cells using Zinc Finger Nucleases and Integrase-Defective Lentiviral Vector Delivery. Nat. Biotechnol. 2007, 25, 1298-1306. [CrossRef] [PubMed]

104. Shariati, L.; Modarressi, M.H.; Tabatabaiefar, M.A.; Kouhpayeh, S.; Hejazi, Z.; Shahbazi, M.; Sabzehei, F.; Salehi, M.; Khanahmad, H. Engineered Zinc-Finger Nuclease to Generate Site-Directed Modification in the KLF1 Gene for Fetal Hemoglobin Induction. J. Cell. Biochem. 2018. [CrossRef] 
105. Popplewell, L.; Koo, T.; Leclerc, X.; Duclert, A.; Mamchaoui, K.; Gouble, A.; Mouly, V.; Voit, T.; Paques, F.; Cedrone, F.; et al. Gene Correction of a Duchenne Muscular Dystrophy Mutation by Meganuclease-Enhanced Exon Knock-In. Hum. Gene Ther. 2013, 24, 692-701. [CrossRef]

106. Mali, P.; Ye, Z.; Hommond, H.H.; Yu, X.; Lin, J.; Chen, G.; Zou, J.; Cheng, L. Improved Efficiency and Pace of Generating Induced Pluripotent Stem Cells from Human Adult and Fetal Fibroblasts. Stem Cells 2008, 26, 1998-2005. [CrossRef]

107. Yang, G.; Si-Tayeb, K.; Corbineau, S.; Vernet, R.; Gayon, R.; Dianat, N.; Martinet, C.; Clay, D.; Goulinet-Mainot, S.; Tachdjian, G.; et al. Integration-Deficient Lentivectors: An Effective Strategy to Purify and Differentiate Human Embryonic Stem Cell-Derived Hepatic Progenitors. BMC Biol. 2013, 11, 86. [CrossRef]

108. Hamilton, A.M.; Foster, P.J.; Ronald, J.A. Evaluating Nonintegrating Lentiviruses as Safe Vectors for Noninvasive Reporter-Based Molecular Imaging of Multipotent Mesenchymal Stem Cells. Hum. Gene Ther. 2018, 29, 1213-1225. [CrossRef]

109. Ortinski, P.I.; O’Donovan, B.; Dong, X.; Kantor, B. Integrase-Deficient Lentiviral Vector as an all-in-One Platform for Highly Efficient CRISPR/Cas9-Mediated Gene Editing. Mol. Ther. Methods Clin. Dev. 2017, 5, 153-164. [CrossRef]

110. Surun, D.; Schwable, J.; Tomasovic, A.; Ehling, R.; Stein, S.; Kurrle, N.; von Melchner, H.; Schnutgen, F. High Efficiency Gene Correction in Hematopoietic Cells by Donor-Template-Free CRISPR/Cas9 Genome Editing. Mol. Ther. Nucleic Acids 2018, 10, 1-8. [CrossRef]

111. Izmiryan, A.; Ganier, C.; Bovolenta, M.; Schmitt, A.; Mavilio, F.; Hovnanian, A. Ex Vivo COL7A1 Correction for Recessive Dystrophic Epidermolysis Bullosa using CRISPR/Cas9 and Homology-Directed Repair. Mol. Ther. Nucleic Acids 2018, 12, 554-567. [CrossRef] [PubMed]

112. Hu, J.; Schokrpur, S.; Archang, M.; Hermann, K.; Sharrow, A.C.; Khanna, P.; Novak, J.; Signoretti, S.; Bhatt, R.S.; Knudsen, B.S.; et al. A Non-Integrating Lentiviral Approach Overcomes Cas9-Induced Immune Rejection to Establish an Immunocompetent Metastatic Renal Cancer Model. Mol. Ther. Methods Clin. Dev. 2018, 9, 203-210. [CrossRef] [PubMed]

(C) 2020 by the author. Licensee MDPI, Basel, Switzerland. This article is an open access article distributed under the terms and conditions of the Creative Commons Attribution (CC BY) license (http://creativecommons.org/licenses/by/4.0/). 